\title{
家畜・家禽の排泄物のメタン醴醅
}

\author{
羽賀 清 典 \\ 農林水産省畜産試験場， \\ 茨城紧筑波農林研究団地 305
}

\section{Methane Fermentation of Livestock and Poultry Wastes}

\author{
Kiyonori HAGA \\ Laboratory of Animal Waste Management, National \\ Institute of Animal Industry, Tsukuba \\ Norindanchi P. O. Box 5, Ibaraki 305
}

畜産業加ら排出される家蓄・家禽の排㳔物は，それを 取巻く状況が不整備なこともあって，悪臭や水質污濁な どの環境污染問題を引起こしてきた ${ }^{1)}$ てそして，この畜 産公害の解決に向けて多くの研究なり技術開発が行わ机 てきだ、しかし，そのように厄介視されてきた排泄物 も，また見方を変えれば貴重な生物資源（パイオマス） であり，肥料化，燃料化，飼料化など栐々な分野での有 効利用が可能である、中でもメタン醗醉法は，比較的手 軽な方法で排泄物汃ら燃料ガ不を生産できることで知ら れ，最近のエネルギー事情も手伝って益々重要性が増し てきている。䄪 4 年每に開催される家畜排泄物処理利用 の国際シンポジウムは，1980 年隹第 4 回大会を迎えた が,そのテーマは「家畜排泄物：再生可能な資源」(Livestock Waste: A Renewable Resource) であった ${ }^{3)}$. そ の報告書に揭載された 119 件の発表の中でメタン醗醉に 関するものは 18 件に及び，饲料化の 21 件に次ぐもので あった．本稿では，家音・家禽排泄物のメタン酸醉研究 についての文献整理し，その現状について概観したい と思う。

\section{1.メタン醴酵の原理とそれに関与する 細菌群}

彷来からタタン醴酵は酸生成過程とガス生成過程の 2 段階反応から成立つと言か和てきだ。しかし，最近に なって細菌学的及び生化学的研究が進むに彷い,メタン

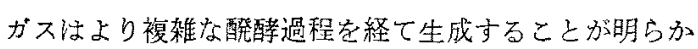

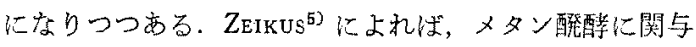
する細菌群はその代謝過程から次の4群に分けられる; I. hydrolytic bacteria (多糖類, 蛋白質, 脂質などの高 分子物質分分解する), II. hydrogen producing acetogenic bacteria（脂肪酸などIの分解物を分解し，酢酸

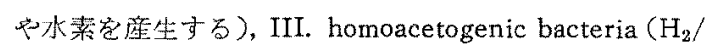
$\mathrm{CO}_{2}$ ，丰酸，I の分解生成物汃酢酸を産生する)，IV. methanogenic bacteria $\left(\mathrm{H}_{2} / \mathrm{CO}_{2}\right.$, 酢酸などからメタン

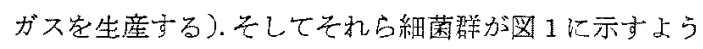
な共生状態を形成しながら，段階的にメタンガス安生産 している。

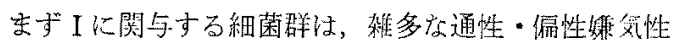
菌が主と思われるが，HOBSONとSHAw

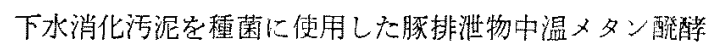
榑（有㗪物負荷 $0.48 \mathrm{kgVS} / \mathrm{m}^{3}$ ・日）に法, $6.4 \times 10^{5} / \mathrm{ml}$

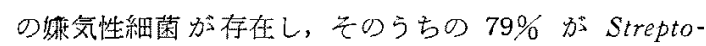
coccusであり，華の他に Clostridium butyricum, Lactobacillusなど加梌出された。また，をれらの基質分解性 加ら女ルロース分解菌 $4 \times 10^{4} \sim 4 \times 10^{5} / \mathrm{ml}$, 一ミ女ルロー 又分解菌 $4 \times 10^{4} / \mathrm{ml}$, 蛋白啠分解菌 $4 \times 10^{2} \sim 4 \times 10^{5} / \mathrm{ml}$ を 計数した. IANNOTTI $5^{7}$ 消消化脱離液念含新しい培地 Medium 174 它考案し, 膘排泄物中温メタン酶酵槽中に

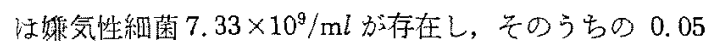
\%当る $3.72 \times 10^{6}$ だけダ aerotolerant bacteria である 


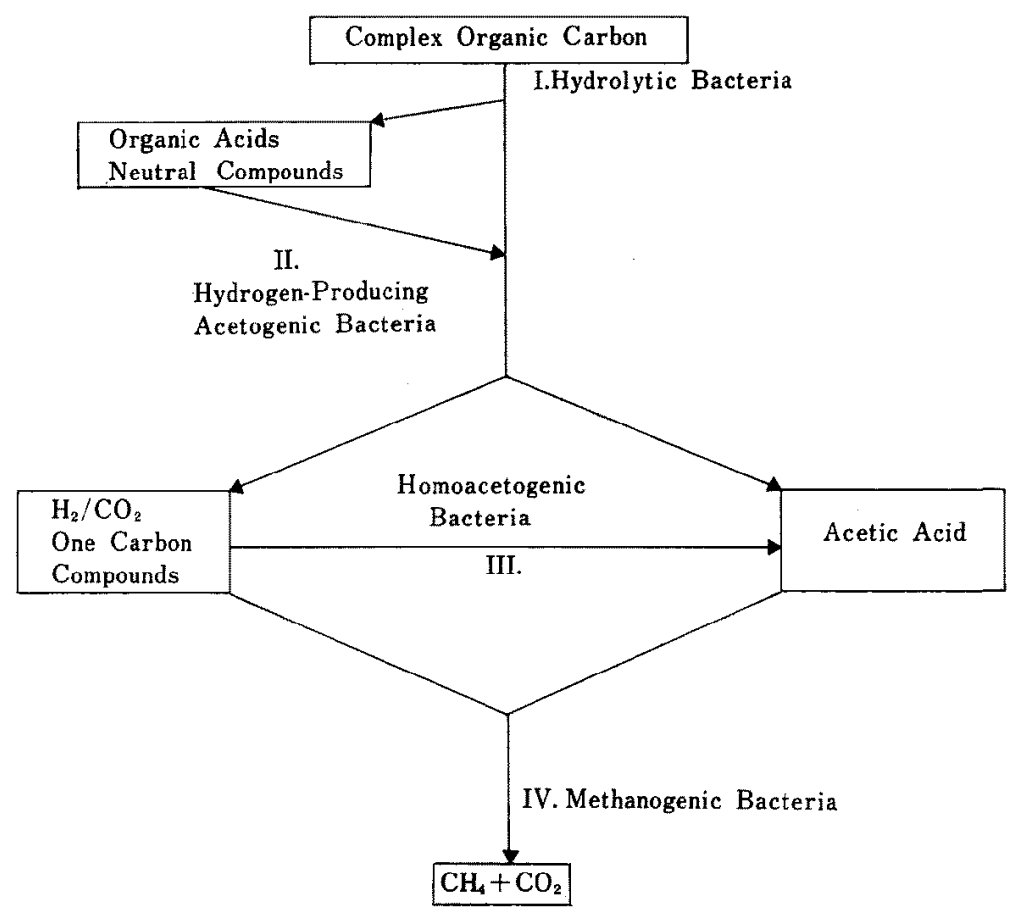

Fig. 1. The Four Bacterial Groups Involved in Methane Fermentation. ${ }^{5}$ )

と述べている，FISCHER らの研究でも豚排泄物中温メタ

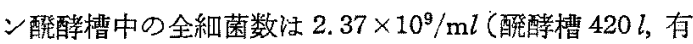
機物負荷 $4 \mathrm{kgVS} / \mathrm{m}^{3}$ ・日 $)^{8)}, 5.6 \times 10^{7} / \mathrm{ml}\left(140 \mathrm{~m}^{3}, 1.3\right.$ $\mathrm{kgVS} / \mathrm{m}^{3} \cdot$ 日) HoBSON のデーダより数 100 倍高いのは, 有機物負荷 の相異によるものと考察している8 ${ }^{8}$. CONVERSE ら ${ }^{10)}$ 法 牛排泄物のメタン醴酔槽中の有機栄盖細菌は, 中温醴醭 の場合 $10^{9} \sim 10^{12} / \mathrm{ml}$ ，高温醴醭の場合 $10^{9} \sim 10^{11} / \mathrm{ml}$ と報 告している.

II, III の細菌群について, MACKIE と BRYANT ${ }^{11)}$ の研 究によれば，牛排泄物のメタン酸酔における酶酸，酪酸 の消長とそれに関与する細菌群を計数した結果，プロピ オン酸の 13〜16\%,酪酸の 7 9\%が II の細菌群の作用て 酶酸安経てメタンへ变㨦されたまた四の細菌群の作用

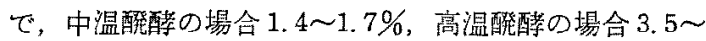
5. $3 \%$ の酶酸が $\mathrm{H}_{2} / \mathrm{CO}_{2}$ からら合成ざれること苋見出した。

IV のメタン細菌がメタンガス生産の主役となるが, Bergey Manual $の 8$ th edition では ${ }^{12)}$, 大きくMethanobacterium, Methanosarcina, Methanococcus $\odot 3$ genus に分類され，その中に法，Methanobacterium soehngenii, $M$. formicicum, $M$. strain $\mathrm{MOH}, M$. thermoautrophicum, M. ruminantium, M. mobile, Methanosarcina methanica, M. barkeri, Methanococcus mazei, M. vannielii の 10 株が記されている. 最近, BALCH ら ${ }^{132}$ は 16S リボソ゚ーム RNA の性状を基本にし， 他飞細咆壁の整造と組成，脂質組成，DNA の GC 含量， メタン生成の基質，代謝経路なぞを加味して新しい分類

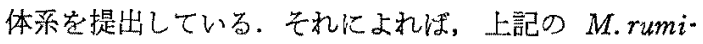
nantium ¿ $M$. arbophilicum 以新たに Methanobrevi* bacter の genus に入れ, M. mobile は Methanomicrobium の genus K入れ, 专の他 Methanobacterium, Methanococcus, Methanogenium, Methanospirillum,

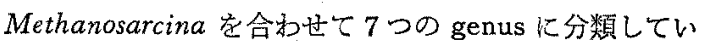
る. そして，その中には 18 種類のメタン細菌を挙げて 斿.

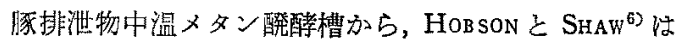
$2 \times 10^{4} \sim 2 \times 10^{6} / \mathrm{ml}$ のメタンン細菌を検出し，それを $M$. formicicum と同定し，その性質を調べている ${ }^{14)}$. 宋た， IANNotTi $5^{7)}$ i $7.8 \times 10^{8} / \mathrm{ml}$, Fischer $5^{8)}$ は $2.3 \times 10^{7} /$ $\mathrm{m} l$ のメタン細菌計数している. CONVERSE $5^{100}$ 注牛

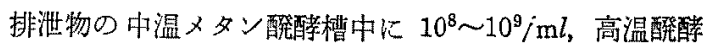
槽中に $10^{9} \sim 10^{11} / \mathrm{ml}$ のメタン細菌計数し, 高温メタン 細菌安 $M$. thermoautrophicum としている. MACKIE と BRYANT $^{111}$ は中温で $3.7 \times 10^{8} / \mathrm{ml}$, 高温で $10.4 \times 10^{8} / \mathrm{ml}$ の メタン細菌定見出している：このように，家畜排泄物の メタン酶酻榑から単離同定されたメタン細菌は 2 種しか 


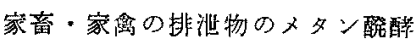

ないが，その数は豚，牛とるに中温で $10^{8} / \mathrm{m} l$ 削後，高 温で $10^{9} / \mathrm{ml}$ 前後と考えられる.

メタンガス生成の生化学的僟構については, 葉酸15),

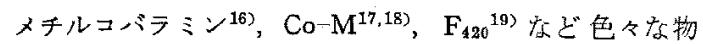
質の関与が举げられているが，末规不明の点加多い，例

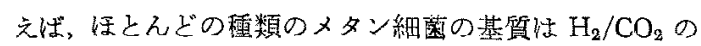

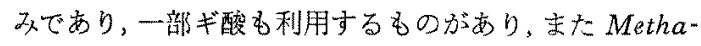
nosarcinaはメタノール，モノメチルアミン，酶酸も利 用することができる ${ }^{13)}$ 、ところが、トレーサーなど崖用 いた実験によればメタンのCの70\%は酷酸の C-2 的来 であり， $\mathrm{CO}_{2}$ 由来のもの注 $30 \%$ 程度である ${ }^{5)}$. 牛排泄物

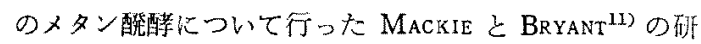
究でも，発生したメタンは中温醗酵の場合 $72 \sim 75 \%$, 高

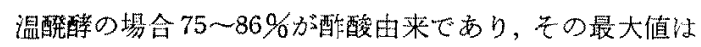
排泄物投入後 2 時間後に観察された。また，MOUNTFORT とASHER ${ }^{20)}$ の呼究で性，投入後 $4 \sim 7$ 時間後はメタンの 90\%か酢酸由来であり, 時間の経過とともに $\mathrm{CO}_{2}$ 由来 のものが增加し，24 时間後には $27.5 \% か ゙ \mathrm{CO}_{2}$ 由来とな $\supset た$.

化学熱力学的に欢て手, $\mathrm{H}_{2} / \mathrm{CO}_{2}$ から口メタン生成反 伈よる自由ェネルギーの変化は；

$$
\begin{gathered}
4 \mathrm{H}_{2}+\mathrm{HCO}_{3}{ }^{-}+\mathrm{H}^{+}-\longrightarrow \mathrm{CH}_{4}+3 \mathrm{H}_{2} \mathrm{O} \\
\left(\Delta \mathrm{G}^{0 \prime}=-135.6 \mathrm{KJ} / \text { reaction }\right)
\end{gathered}
$$

と大きいのに刘し; 酢酸の埸合には;

$$
\mathrm{CH}_{3} \mathrm{COO}^{-}+\mathrm{H}_{2} \mathrm{O} \longrightarrow \mathrm{CH}_{4}+\mathrm{HCO}_{3}^{--}
$$

( $A \mathrm{G}^{0 \prime}=-31.0 \mathrm{~kJ} /$ reaction)

であり,からうじて $1 \mathrm{~mol} の$ ATP 生成 $\left(A \mathrm{G}^{\alpha}=-30.6\right.$ $\mathrm{kJ)}$ 加可能な量にし名方ず，乙れではメタン細菌の成 長を支えるには之しい量と言えよう211，以上のように， この分野もま汧究の余地老十分に残しているものと考 えられる。

\section{2. 家甾・家禽の排泄物のメタン醗酵}

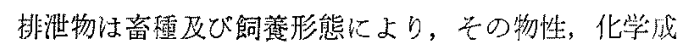
分などが著しく異なる。そこで，各童整に分け，そのメ

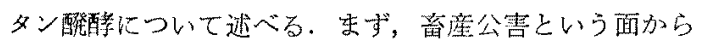
も，最石研究洌の多い豚及ら始めることにする。

2-1. 豚排灌物のメタン醅酵

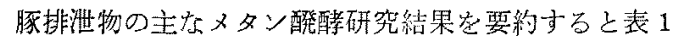
の上うになる。中温醴酵 $\left(30 \sim 40^{\circ} \mathrm{C}\right)$ において，約 $2 \sim 3$

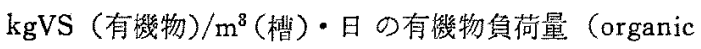
loading) で, 㴆留日数 (detention time) が10 30日と いう条件で, 有嘰物 (VS) $1 \mathrm{~kg}$ 当り $300 \sim 500 \mathrm{l}$ のメダン

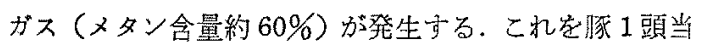

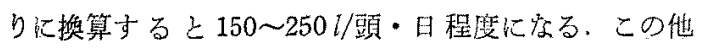

IFEADI ¿ BROWN ${ }^{39)}$ 㳊 $108 \sim 374 l /$ 䫓・日, MORRIS $5^{40)}$ は

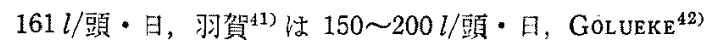
は $178 \mathrm{l} /$ 歌・日，MEYNELL ${ }^{\mathfrak{1} 3)}$ は $240 \mathrm{l} /$ 䫑・日，カナダの Biomass Energy Institute ${ }^{44)}$ は $157 /$ 頭・日という值を 提出しており，㤬200l前後の発生量が平均值である。

JEWELL と LOEHR ${ }^{457}$ のとりまとあによると, 有機物筫 荷 $3 \mathrm{~kg} / \mathrm{m}^{3}$ ・日以上になると有機物の分解犁加低下す る. また, VAN VELSEN ${ }^{30}$ の实験では, $5.4 \mathrm{~kg} / \mathrm{m}^{3}$ ・日で

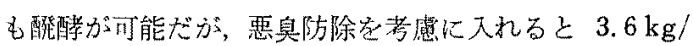
$\mathrm{m}^{3}$ ・日が遥当であるとしている. 投入固形物浱度 (TS) くついて姑，SUMMERSとBOUSEIELD ${ }^{37)}$ の研究によれば，

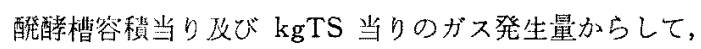
6\%ぐらいが適切であるしている。そして，心えと尿の

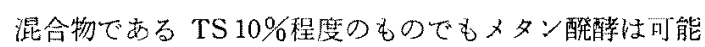
であるが，ポンプ搬送などの機械的面や，後述のアンモ ニフ態空素浱度の点からも，上記 TS 源度が適当である 己述ベている。

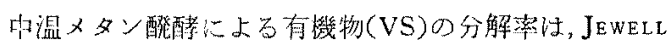
と LOEHR ${ }^{45)}$ のとりまとめによると約 $50 \%$ となっいる が, TAIGANIDES $5^{22)}$ は 60〜70\%, GRAMMS $ら^{23)}$ は 49〜

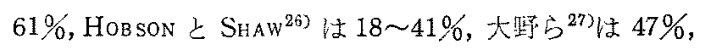
VAN VELSEN ${ }^{30}$ ) 仕 $32 \sim 49 \%$, 羽賀 ${ }^{34)}$ は 41\%, FISCHER $5^{8)}$ は $63 \%$ ，藤田 ${ }^{36)}$ は $35 \%$ という数字定出しており, 匢㭱 30〜50\%が可均的な数字と思われる。また前述のガ

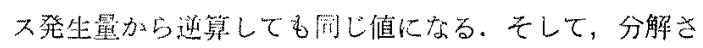
孔る有㙨物の分四について快, HoBson ट SHAw ${ }^{26)}$ の研 究では, 檓脂肪の $64 \%$, Neutral detergent fiber $の$ $40 \%$, Acid detergent fiber の $20 \%$ が分解され, リグ ニンは全く分解されな放った、VAN VELSEN ら ${ }^{46)}$ は, 一 ミセルロースの 43\%, セルロースの 39\%が, SUMMERS とBOUSFIELD ${ }^{37}$ は脂肪の 53\%，七ルロースの $41 \%$ ，人 ミセルロースの 48\%が分解されたというデータ安提出 している.

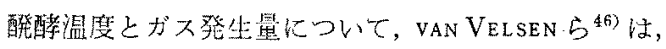
TS6\%,TS 筫佰 $4 \mathrm{~kg} / \mathrm{m}^{3} \cdot$ 日，滥留日数 15 日という条

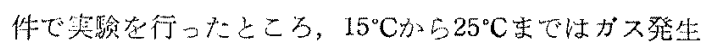

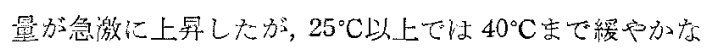

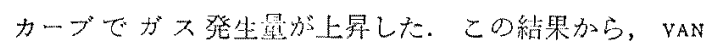
VELSEN ら活 $27 \sim 30^{\circ} \mathrm{C}$ が 経済的湿膺としている. SUMMERS と BOUSFIELD ${ }^{37}$ の実雅では, 洲留日数 10 日の場合, $35^{\circ} \mathrm{C}$ のガス発坐墨肺 $300 \mathrm{l} / \mathrm{kg}$ TS で方るのに対し, 25 ${ }^{\circ} \mathrm{C}$ で $260 l, 30^{\circ} \mathrm{C}$ で $300 l, 40^{\circ} \mathrm{C}$ で $360 l, 44^{\circ} \mathrm{C}$ で $420 l$ であっ

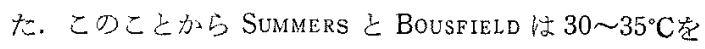
最適な温度としている。黑田と油川 ${ }^{38)}$ 性 $20 \sim 37^{\circ} \mathrm{C}$ の触

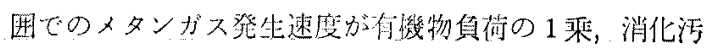


羽 嘿

Table 1. Methane Fermentation of Swine Wastes

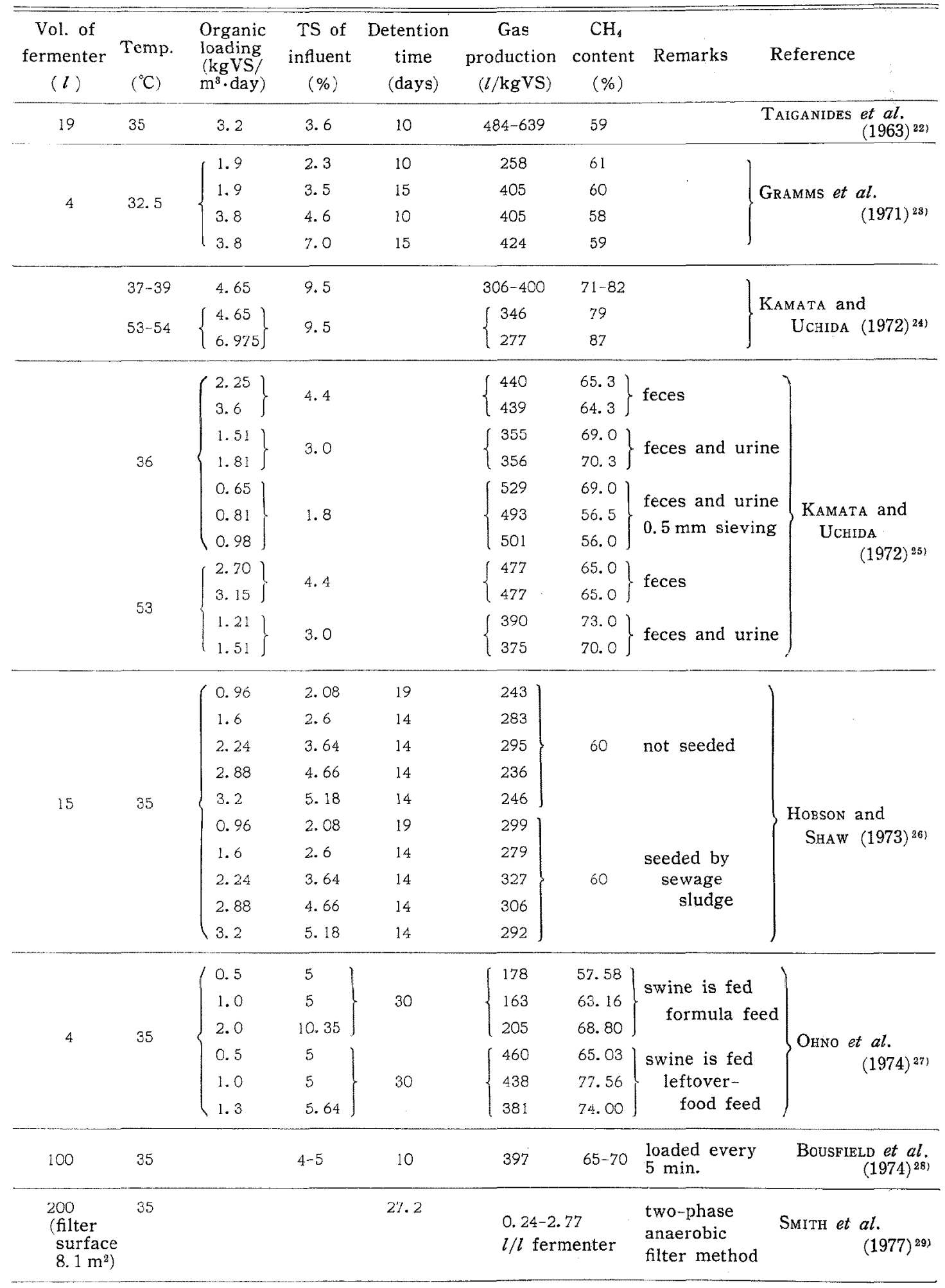




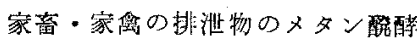

Table 1. (Continued)

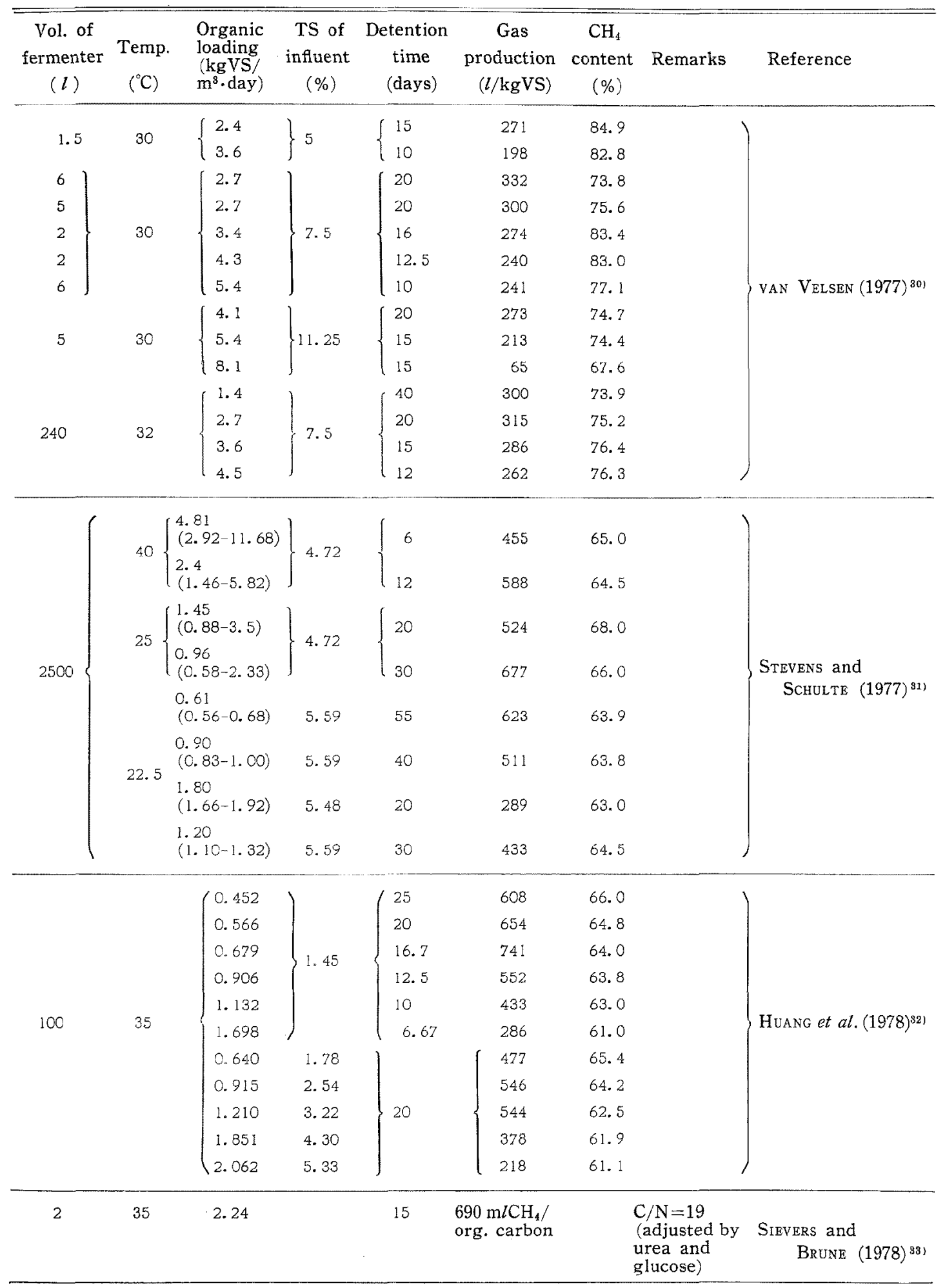


Table 1. (Continued)

\begin{tabular}{|c|c|c|c|c|c|c|c|c|}
\hline $\begin{array}{c}\text { Vol. of } \\
\text { fermenter } \\
(l)\end{array}$ & $\begin{array}{l}\text { Temp. } \\
\left({ }^{\circ} \mathrm{C}\right)\end{array}$ & $\begin{array}{l}\text { Organic } \\
\text { loading } \\
\text { (kgVS/ } \\
\mathrm{m}^{3} \cdot \text { day) }\end{array}$ & $\begin{array}{c}\text { TS of } \\
\text { influent } \\
(\%)\end{array}$ & $\begin{array}{c}\text { Detention } \\
\text { time } \\
\text { (days) }\end{array}$ & $\begin{array}{c}\text { Gas } \\
\text { production } \\
(l / \mathrm{kgVS})\end{array}$ & $\begin{array}{c}\mathrm{CH}_{4} \\
\text { content } \\
(\%)\end{array}$ & Remarks & Reference \\
\hline 150 & 35 & 3.2 & 7.7 & 20 & $350-400$ & 62.2 & & HAGA et al. $(1979)^{34)}$ \\
\hline 420 & 35 & 4 & 7.3 & 15 & 575 & 59 & & FISCHER et $a l .(1979)^{8)}$ \\
\hline $140\left(\mathrm{~m}^{3}\right)$ & & 1.3 & $1-5(\mathrm{VS})$ & & $\begin{array}{l}0.9 \mathrm{~m}^{3} / \mathrm{m}^{3} \\
\text { fermenter }\end{array}$ & $55-60$ & & FISCHER et $a l .(1979)^{9)}$ \\
\hline 20 & 35 & $\left\{\begin{array}{l}5 \\
2.5 \\
1.65 \\
1.25\end{array}\right\}$ & 6.25 & $\left\{\begin{array}{l}10 \\
20 \\
30 \\
40\end{array}\right.$ & $\begin{array}{l}457 \\
502 \\
525 \\
540\end{array}$ & & & PARK et al. $(1979)^{35)}$ \\
\hline 30 & 39 & $\begin{array}{c}2.68 \\
\left\{\begin{array}{c}1.34 \\
2.68 \\
5.36 \\
10.71\end{array}\right\}\end{array}$ & 6 & $\left\{\begin{array}{r}16 \\
32 \\
16 \\
8 \\
4\end{array}\right.$ & $\begin{array}{l}264 \\
328 \\
252 \\
274 \\
220\end{array}$ & $\begin{array}{l}62.9 \\
62.7 \\
62.3 \\
66.3 \\
64.9\end{array}$ & & Fujlta $(1980)^{367}$ \\
\hline 100 & 35 & 4.2 & 6 & 10 & 430 & 69 & $\begin{array}{l}\text { loaded every } \\
5 \text { min. }\end{array}$ & $\begin{array}{l}\text { y Summers and } \\
\text { BovsfIELD }(1980)^{371}\end{array}$ \\
\hline 28 & 37 & $0.6-1.8$ & $1.1-3.13$ & 7 & 410 & 68 & & $\begin{array}{l}\text { KURODA and } \\
\text { YUKAWA }(1980)^{38)}\end{array}$ \\
\hline
\end{tabular}

泥灌度の0.3乘に比例し、温度の上界につれて增加するこ 之在示した，FEILDEN ${ }^{47}$ 恬投入TS浱度が $3.5 \%$ 以下なら

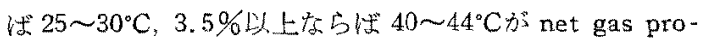
duction のための適湿であるしてている。た，本多48)

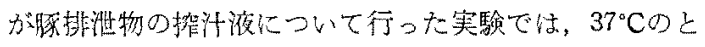
きのガス発生量を 100 とした場合， $31^{\circ} \mathrm{C} て ゙ 97.6,25^{\circ} \mathrm{C}$ で 90.4でかり，25ㄷ 以下では急激にガス発生量が低下

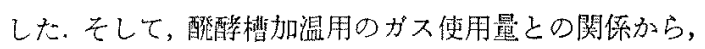
$28^{\circ} \mathrm{C}$ 唯最も経済的な温度としている。高温醴酳（50〜

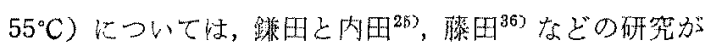

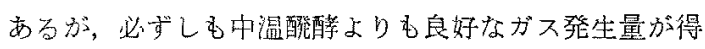

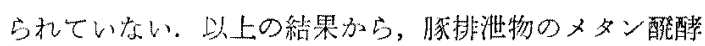

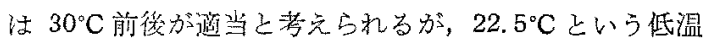

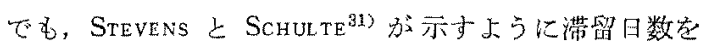

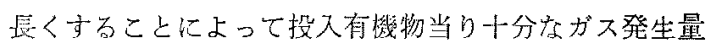

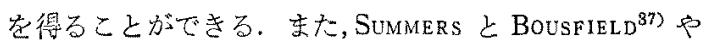
御園 ${ }^{499}$ 占指摘子るように，5 $5^{\circ} \mathrm{C}$ 以下の急激な温度低下は ガス発生量总減少させる。

投入物の C/N については Sievers \& BRUNE ${ }^{33)}$ の研 宛がある。尿絜とダルコースを添加して溷排洮物の $\mathrm{C} / \mathrm{N}$

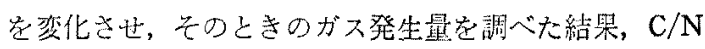

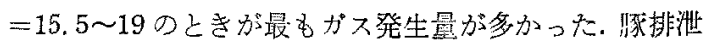

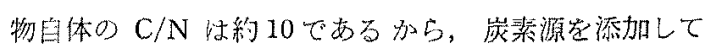

C/Nを上晶させることは，ガス発生量た買加させ，加つ アンモニフ態空素による醴醉阻害を防止する意味でも有

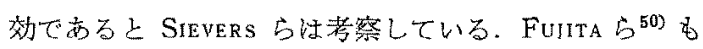
炭素源としてのコーンストーバの添加効果定研究した結 果, コーンストーバの炭素分の50\%がガスに転鼬され， 消化污泥の蛋白質含量が增加することを示している。

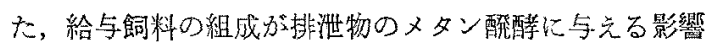

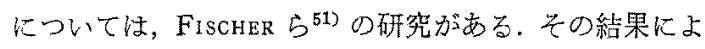

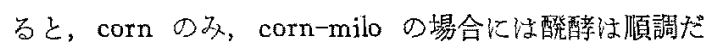
加, corn-wheat にするとガス発生量が低下し，スカ厶 生成によるパイプの閉塞などの障容が起さた。

$\mathrm{C} / \mathrm{N}$ の低いときにはアンもニア態壆菜による醗酵阻 害, $\mathrm{C} / \mathrm{N}$ が高い乞きには揮発性脂肪酸による阻害が考息

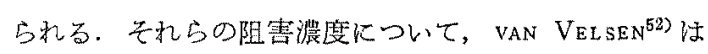

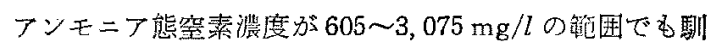
化されて十分ながス発生量唯あることを示している。黑

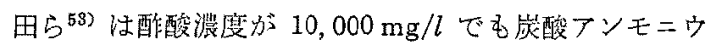
ムで中和して $\mathrm{pH}$ 至 7〜8 亿保てば正常な醗䣼が行bれ

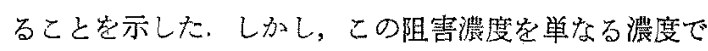
判定することは能しく、イオンの形態の相異や，他のイ

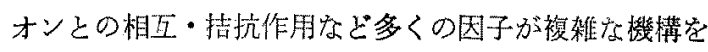
形成しているようである ${ }^{54)}$. KROECKER $5^{55)}$ の知見によ

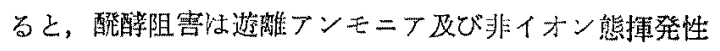


有譏酸によるものが大きく，特に後者が $30 \sim 60 \mathrm{mg} / l$ で る阻害功見られた. HILLと NORDSTEDT ${ }^{56)}$ 任非イオン態 揮発性有機酸及びアンモニアが細菌類の成厔速度に与光 る影響や，炭素・窒素化合物のマスバランスなどを因子

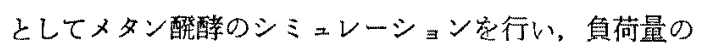
高い場合の有機酸やアンモニウムイオンの蓄積, $\mathrm{pH}$, ガ ス量の低下などを示した。また，HOBSON と SHAW ${ }^{14}$ は 豚排泄物メタン醗酵槽加ら単離した $M$. formicicumに

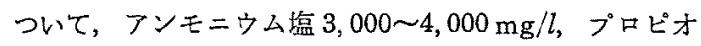
ン酸塩 $1,000 \sim 5,000 \mathrm{mg} / l$ で顕著な阻害があることを示 した.このことは，醀醉が十分に進行しないときに蓄樻 する有機酸がブロピオン酸であること融,58) と閣連して 興味ある結果である、その他の阻害物としては，飼料中

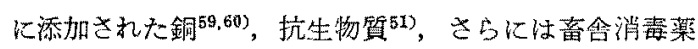

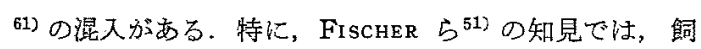
料中に添加された lincomycin で显著な酸酝阻害が起き た.

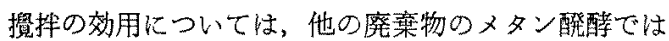
いくつかの物型的・生化学的効果肪指摘されているが

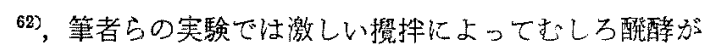

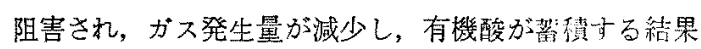

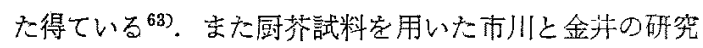

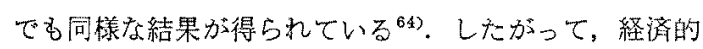

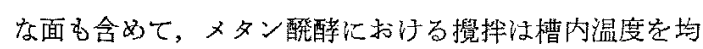

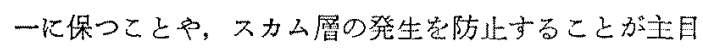
的にならう。古くから使用されている小野の装置でもス カ厶層を粉砕する目的の攪䢁棒が設置されているだけで ある65).

メタン醴酵は密閏槽で行われることや，豚排泄物中 の悪臭物質がメタン，二酸化宸素などに分解されるこ とから，悪臭防除法としてもメタン酶酤は重要である。 WELSH $5^{66)}$ は，系気の快・不快度を基本にした 11 段階 (0〜10) の官能テス卜法によってその評価焉している が，投人物で 6.5 であったものが，処㻎物では4.6に娍 少し， $25^{\circ} \mathrm{C}$ のタン醗酵のものより $35^{\circ} \mathrm{C}$ 方が悪臭が少

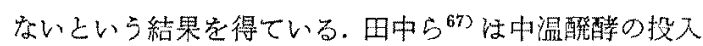
物と処理物の臭気漕度，臭気強度，不仭度，またインド 一ル, スカトール, p-タレン゙ール, アンキ二フ, トリメ チルアミン, 硫化水亲, メチルメルカプタン, ジメチル サルファイド, ジメチルジサルファイド, 酶酸, プロピ オン酸，酪酸などの泟度を測定し，悪总防除に刘する有

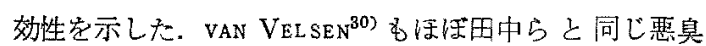

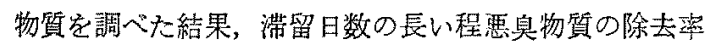
が高く，投入物濃度が低い程インドール，スカトールの

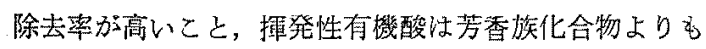

速やかに分解されることを示した。そして，投入 TS 濃度 $7.5 \%$ ，滞留日数 15 日のとに満足な悪奥除去方 できるとしている、专た，発生したかタンガス中に含ま れる硫化水素の除去については，乾式脱碢用 ${ }^{68,692}$, 石兏

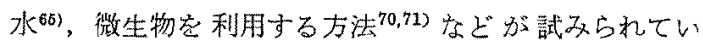
马.

以上のように，豚排泄物のメタン醀醉について述べて

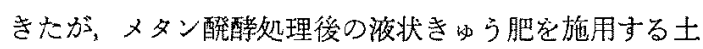
地它持たない場合が多く，これが普及のネックのひとつ になっている。また，発生したメタンガスの使途として は, 農家の日常生活用, 子豚の哺育箱の熱源, 発電して 豚舎のフォンの運転などが考えられる.

\section{2-2. 牛排泄物のメタン醴酵}

牛排泄物のメタン醗醉の主な研究絬果を要約すると表 2のようになる。表中，特にことるっていないものは乳 牛の排泄物の研究でる。.1971年むでの研究では中温釀 酵のガス発生量は投入VS $1 \mathrm{~kg}$ 当り $100 \mathrm{l}$ ほどであった が，最近の研究で估 $200 \sim 350 l$ が平均的な值と考兄られ る.これは研究手法の進歩とともに, 飼料の質の变化も

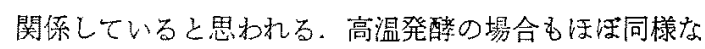
值であり，投入VS 当りのガス発生量において高温醴醭 の方特に榎れているということはない，ただし，高温

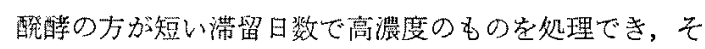

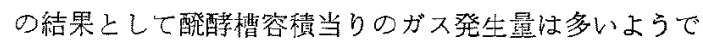
ある.ガス発生星老牛 1 頭当りに換算すると700 1,200

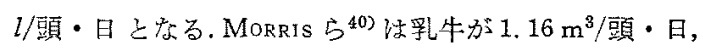
肉牛が $1.12 \mathrm{~m}^{3} /$ 䪷・日，IFEADI $2 \mathrm{BrOWN}^{399}$ 䚾乳牛が $1.19 \sim 1.7 \mathrm{~m}^{3} /$ 頭 -日, 肉牛が $0.85 \sim 1.02 \mathrm{~m}^{3} /$ 頭・日, カナダの Biomass Energy Institute ${ }^{44)}$ は乳牛 $1.48 \mathrm{~m}^{3}$ / 頭・日，肉牛 $1,2 \mathrm{~m}^{3}$ /頕・日という值它提出しており， 釈牛・肉牛と子は $1 \mathrm{~m}^{3}$ 頭・日くららいの值が平均值と 思名れる。

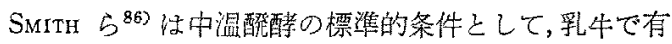
機物真荷 $6 \mathrm{~kg} / \mathrm{m}^{3} \cdot$ 日，滞留日数 15 日，肉牛では各々

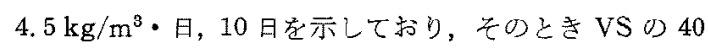

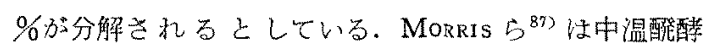
$\left(32.5^{\circ} \mathrm{C}\right)$ の满留日数, 投入 TS 㵵度, 有機物負荷などの

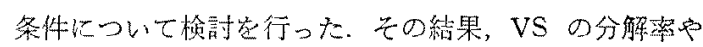
ガス生成量からして滞留日数は10日以上とる必要があ

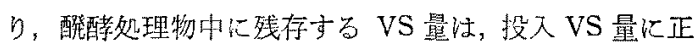
比例し涩留日数に法反比例すること定数式的に示した。 また投入 TS 浱度は6〜8\%ぐらいが適当であり、ポンブ 搬送や攪排などの機械的見地加ら文て $10 \%$ が上限で あるらと述べている。しかし $\mathrm{HnLs}^{802}$ は才一ガ方式の

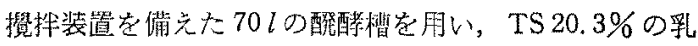


羽 潩

Table 2. Methane Fermentation of Cattle Wastes

\begin{tabular}{|c|c|c|c|c|c|c|c|c|}
\hline $\begin{array}{l}\text { Vol. of } \\
\text { fermenter } \\
(l)\end{array}$ & $\begin{array}{l}\text { Temp. } \\
\left({ }^{\circ} \mathrm{C}\right)\end{array}$ & $\begin{array}{l}\text { Organic } \\
\text { loading } \\
\text { (kgVS/ } \\
\mathrm{m}^{\mathrm{a}} \cdot \text { day) }\end{array}$ & $\begin{array}{c}\text { TS of } \\
\text { influent } \\
(\%)\end{array}$ & $\begin{array}{l}\text { Detention } \\
\text { time } \\
\text { (days) }\end{array}$ & $\begin{array}{c}\text { Gas } \\
\text { production } \\
(l / \mathrm{kgVS})\end{array}$ & $\begin{array}{c}\mathrm{CH}_{4} \\
\text { content } \\
(\%)\end{array}$ & t Remarks & Reference \\
\hline \multirow{4}{*}{3.41} & 23 & 2.1 & \multirow{4}{*}{10.08} & 25.7 & 76.4 & 52 & & \multirow{4}{*}{ HART $(1963)^{72)}$} \\
\hline & 35 & 2.1 & & 26.3 & 154.7 & 65 & & \\
\hline & 23 & 3.2 & & 26.3 & 103.8 & 59 & & \\
\hline & 35 & 3.41 & & 25.3 & 144.5 & 59 & & \\
\hline \multirow{4}{*}{10} & \multirow{4}{*}{35} & \multirow{3}{*}{1.6} & 2.39 & 12 & 54.4 & 77 & & \multirow{4}{*}{$\begin{array}{l}\text { DALRYMPLE and } \\
\quad \text { PROCTOR }(1967)^{73)}\end{array}$} \\
\hline & & & 3.97 & 20 & 48.7 & 79 & & \\
\hline & & & 7.22 & 20 & 35.5 & 77 & & \\
\hline & & 2.88 & 4.34 & 12 & 65.0 & 74 & & \\
\hline \multirow{4}{*}{4} & \multirow{4}{*}{32.5} & \multirow{3}{*}{1.92} & 2.48 & 10 & 63.4 & 65.8 & & \multirow{4}{*}{ GRAMMS et al.(1971) ${ }^{23 !}$} \\
\hline & & & 3.72 & 15 & 80.3 & 64.9 & dairy bull & \\
\hline & & & 4.95 & 10 & 72.2 & 65.2 & wastes & \\
\hline & & 3.84 & 7.43 & 15 & 97.7 & 61.31 & & \\
\hline \multirow{8}{*}{710} & \multirow{5}{*}{35} & 4.26 & 14.7 & 15 & 365 & \multirow{8}{*}{\multicolumn{3}{|c|}{$\begin{array}{l}53.1 \text { feces } \\
52.8 \text { feces, urine and bedding } \\
53.3 \text { feces, urine and bedding } \\
50.6 \text { feces and urine } \\
49.2 \text { feces } \\
50.2 \text { feces, urine and bedding } \\
50.6 \text { feces, urine and bedding } \\
54.5 \text { feces and urine }\end{array}$}} \\
\hline & & 4.31 & 14.8 & 15 & 373 & & & \\
\hline & & 6.12 & 15.1 & 10.4 & 243 & & & \\
\hline & & 6.22 & 15.5 & 10. 4 & 266 & & & \\
\hline & & 4.23 & 14.6 & 15 & 268 & & & \\
\hline & \multirow{3}{*}{60} & 4.28 & 14.7 & 15 & 246 & & & \\
\hline & & 9.90 & 15.4 & 6.2 & 209 & & & \\
\hline & & 10.51 & 15.8 & 6.2 & 249 & & & \\
\hline \multirow{4}{*}{3} & \multirow{4}{*}{60} & 27.3 & $8.2(\mathrm{VS})$ & 3 & $160\left(\mathrm{CH}_{4}\right)$ & \multirow{4}{*}{\multicolumn{2}{|c|}{$\begin{array}{r}\text { dairy-beef } \\
\text { steer wastes }\end{array}$}} & \multirow{4}{*}{ VAREL et al. $(1977)^{n \mathbf{1}\}}$} \\
\hline & & 16.7 & $10.0(\mathrm{VS})$ & 6 & $180\left(\mathrm{CH}_{4}\right)$ & & & \\
\hline & & 12.9 & 11.6 (VS) & 9 & $200\left(\mathrm{CH}_{4}\right)$ & & & \\
\hline & & 9.7 & $11.6(\mathrm{VS})$ & 12 & $220\left(\mathrm{CH}_{4}\right)$ & & & \\
\hline \multirow{6}{*}{1} & \multirow{6}{*}{37.5} & $8.97)$ & \multirow{6}{*}{7.6} & $(7.5$ & 222 & 64 & & \multirow{6}{*}{$\begin{array}{l}\text { Patelunas and } \\
\qquad \text { REGAN }(1977)^{75}\end{array}$} \\
\hline & & 6.72 & & 10 & 241.2 & 64 & & \\
\hline & & 4. 48 & & 15 & 253.6 & 65 & & \\
\hline & & 3.36 & & 20 & 295.7 & 65 & & \\
\hline & & 2.72 & & 25 & 267.8 & 69 & & \\
\hline & & $(2.24)$ & & 30 & 261.0 & 69 & & \\
\hline 150 & 35 & $\{3(\mathrm{TS})\}$ & 6 & 10 & $195(\mathrm{TS})$ & $55-60$ & & BOUSFIELD et $a l$. \\
\hline & & $\{4(\mathrm{TS})\rfloor$ & & 20 & $215(\mathrm{TS})$ & & & $(1979)^{76\}}$ \\
\hline 15000 & ca. 25 & 0.95 & 8.5 & 75 & 240 & $60-70$ & $\begin{array}{l}\text { a KVIC pl } \\
\text { in India }\end{array}$ & $\begin{array}{l}\text { lant RAJABAPAIAH } \\
\text { et al. }(1979)^{77)}\end{array}$ \\
\hline & & 5.2 & & 10 & 259 & & & \\
\hline 20 & 35 & 2.5 & 6,25 & 20 & 350 & & & $\mathrm{PABK}_{\mathrm{AB}}$ et $\alpha \mathrm{l}(1979)^{35 \mathrm{~F}}$ \\
\hline 20 & ov & 1.65 & 0.20 & 30 & 393 & & & FARK el al. (19/Y) \\
\hline & & & & 40 & 435 & & & \\
\hline & 55 & 16 & & 5 & 300 & 50 & $\begin{array}{l}\text { beef cattle } \\
\text { wastes }\end{array}$ & $\begin{array}{l}\text { HASHIMOTO et } a l . \\
\qquad(1979)^{78,79)}\end{array}$ \\
\hline
\end{tabular}


Table 2. (Continued)

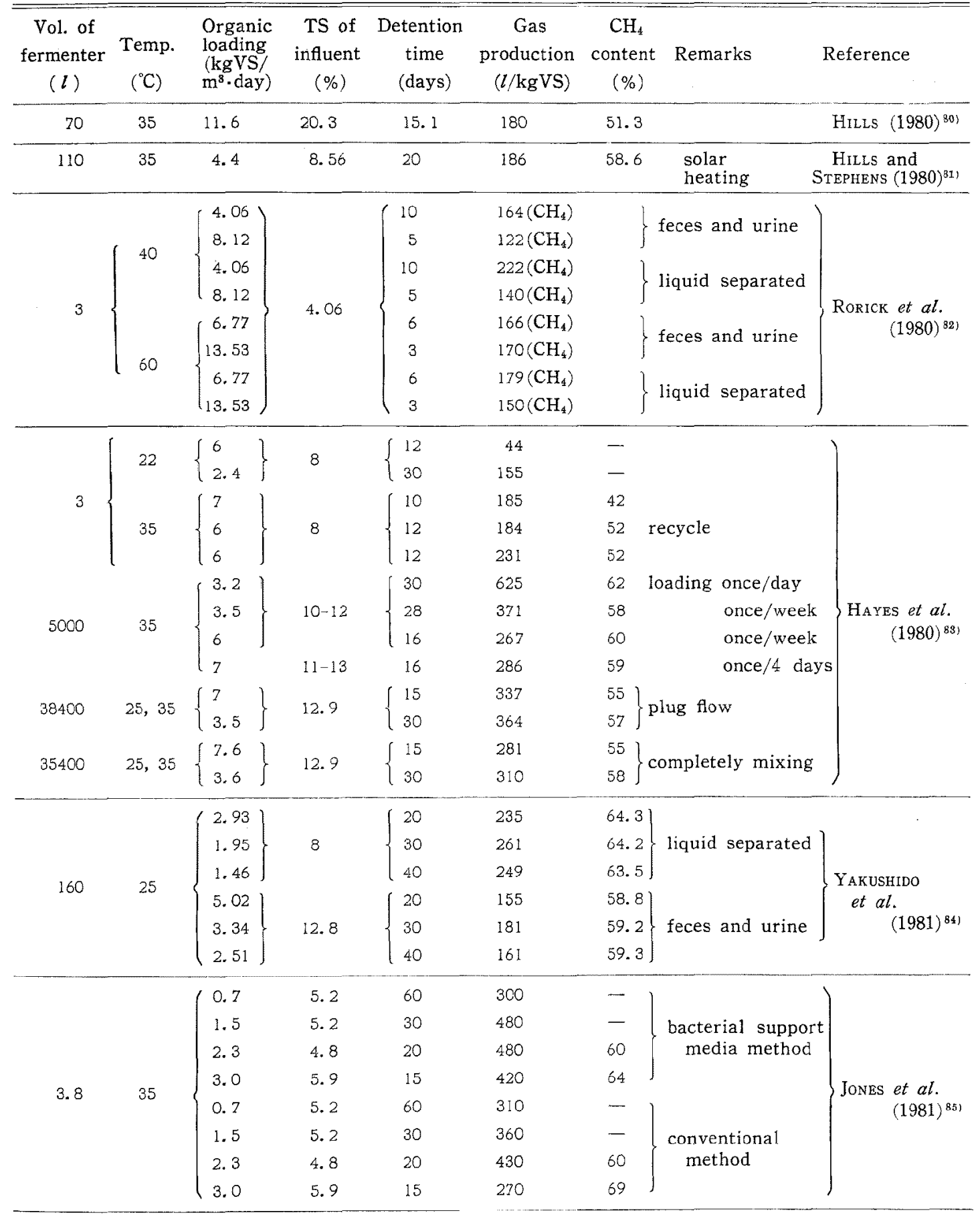

牛排泄物を稀釈せずにメタン醴酵した。バッチ式ではす るが, WONG-CHONG ${ }^{88)}$ は dry anaerobic digestion $と い$

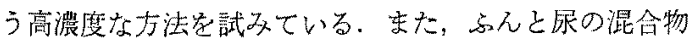

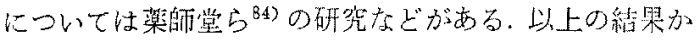
ら，排浛物稀嘌せずに，前記の上うな機械的面老解決

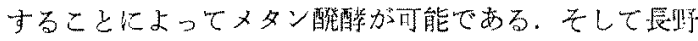




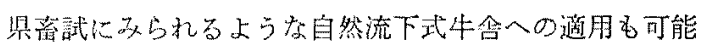

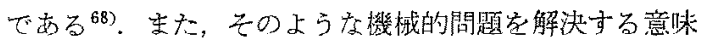

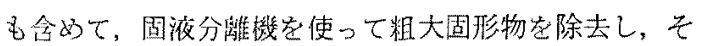

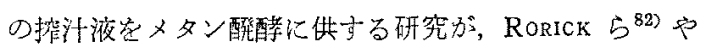
蒋的堂ら ${ }^{84)}$ によって行われている。これら以いずれる分

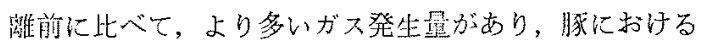
同椂な力法の本多 ${ }^{48}$ の研究とともにその発展加期待さ れる。

高温酩酵については, 乳牛排沺物で CONVERSE ら、デ イリービーフー゙ VAREL ら, 肉牛排湴物て HASHMOTO

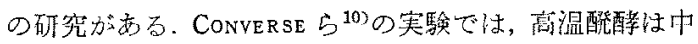
渭配醋に比べあまり良い成續を示していないが，VAREI $ら^{74}$ は蓱留日数 3 日，投入VS濃度 $8.2 \%$ も良好なメ

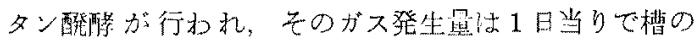

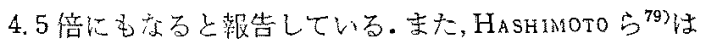
肉牛排沚物の高温入タン醴酷によってェネルギー生産灾

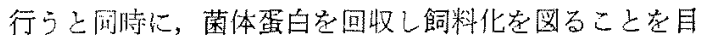
的として研究老行っている。彼らの提示している醴酷

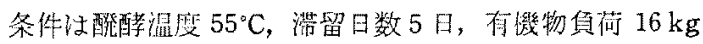
$\mathrm{VS} / \mathrm{m}^{3}$ ・日である。

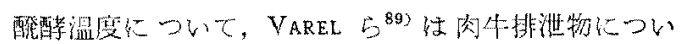

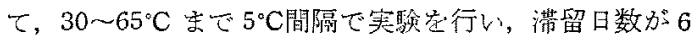
日以上斿的 $40 \sim 60^{\circ} \mathrm{C}$ で嵲当りのガス発生量に大差の

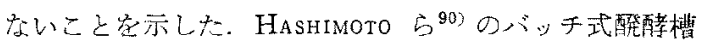

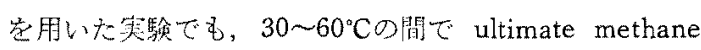
yield $\left(l \mathrm{CH}_{4} / \mathrm{g}\right.$ VS)に㾏がなかった. PARK $5^{35)}$ は $35^{\circ} \mathrm{C}$

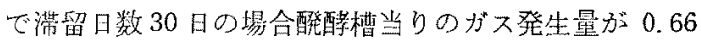
$l / l$ ・日であったものが, $30^{\circ} \mathrm{C} て 30$ 日の塌食 $0.58 l / l$.

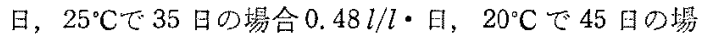
合 $0.42 l / l \cdot 日, 15^{\circ} \mathrm{C} て ゙ 60$ 日の場合 $0.24 l / l$ 日と減少

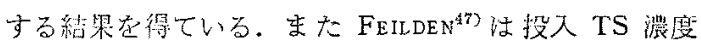
づ 7.5\%以下ならば $25 \sim 30^{\circ} \mathrm{C}, 7.5 \%$ 以上ならば 40〜

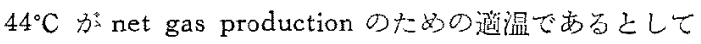
W.

投入物の C/Nについては，乳牛排泄物の籍到滤液に

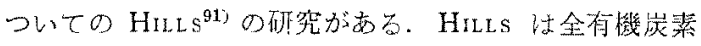
からリダニン態炭素东引いたものを available carbon

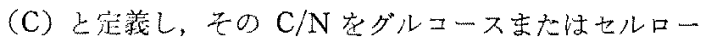
スの添加によって 8〜51.7の制国で变化させ，中温メタ

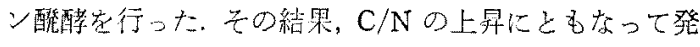

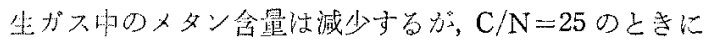

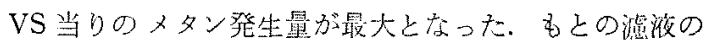
C/Nは8でることから，ここでも炭菜源添加の效果が 示睃された。

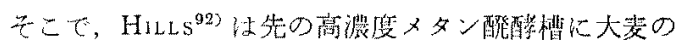

ワラ在潦加し $\mathrm{C} / \mathrm{N}=30$ で笑驗を行ったとこち，12.5 kg $/ \mathrm{m}^{3}$ ・日の高焦荷です，槽容積の 2.46 倍のガスが発生 し，25日の滞留日数でへミセルロースの 26.7\%, セルロ 一スの $28.4 \%$ ，リグニンの6.3\%が分解されたという結 果老得た. そして非リグニン態炭素のメタンへの变撸効 率を測定すると、ワラ添加の効果が大きいことを宗した。 さらに HuLLs と ROBERTS ${ }^{932}$ はイナワラとモミガラの添

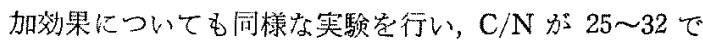
最大の効果定得ている. ROBBINS $5^{943}$ もルロース添加 の効果奆示し，また脱りダニン処理したワラダ叔处理の ものより2倍の殾果のあること学明らかにした。 LAURA

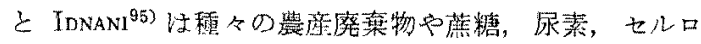
一スなどを添加した結果，セルロース添加はがス発生悬 を增加させたがメタン含量影低下させた，焉た尿や力ゼ インなどの含窒素化合物でもが不発生量が增加したと述 ベている. JAIN $5^{96}$ の研究では，羊の排泄物壱添加する と牛排沮物のセルロース分解率とがス発生量名 5 10\% 上䒜する。

飼料中に添加された抗生物質はメタン醴酵に悪影塖 を及ぼ寺、VAREL と HASHIMOTO97) の研究によれば，

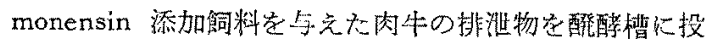
入したところ，9日間でメタンガス発生が全く停止し，

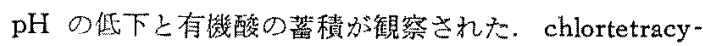
cline の場合は20\%だけガス発生量が低下しただけであ

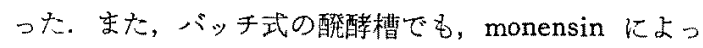
てメタンガスの発生開始が 40 日余り遅れたが, その後は

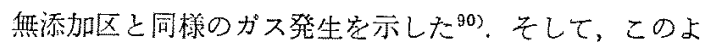
らな抗生物筫による酸酳阻害ならびに則化機權について は,ルーメン代謝の睡往の研究成果に照らして考察が加

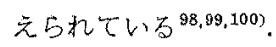

最後に，メタン醴醉榑の形式として特徵あるものを挙 げると, HAYES $5^{83)}$ の簡易な plug flow 万式, HiLLs と STEPHENS ${ }^{81)}$ のソーシ加熱方式, 固定床式の一種であ る Jones $5^{85}$ の fiber wall reactor (FWR) 方式, dら にはせミ・バッチ方式と言光る HuLs ら ${ }^{101)}$ の continuously expanding digester (CED) 万式などがある。

以上の上うに牛排泄物のメタン醴醉について述べてき

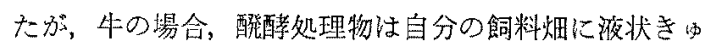
う肥の班で有效に施用できるここが多く，膘のようにて の処理に困るようなことは少ない。虬しる，排浛物中に

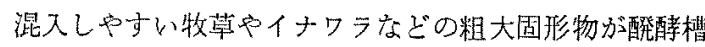
の機械的トラブルの原因となるような別の閒題がある う、発生したガスは，酪絮の場合には作策用の湿水やミ ルカー用発電など㐬座用ェネルギーとしての需要も多

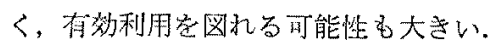




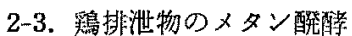

鵎排泄物のメタン醇酧の主な研究結果を要約すると 表 3 のうになる。中温醴醭で投入VS $1 \mathrm{~kg}$ 当り $300 \sim$ $600 l$ のメタンガスが発生する. 前の 2 畜種に比べて研 究例屯少なく, データのハトラッキも大きい. 1 羽当り
のガス発生量にすれば，6.75 13.5 l/ 羽・日である。 MORRIS $5^{40 \%}$ は $13.8 \mathrm{l} /$ 羽・日, GOLUEKE ${ }^{423}$ 性 $11.3 \mathrm{l} /$ 羽 ・日, MEynell ${ }^{43)}$ は $14 l /$ 羽・日，カナダの Biomass Energy Institute ${ }^{44)}$ は $12.4 \mathrm{l} /$ 羽・日という值を提山して

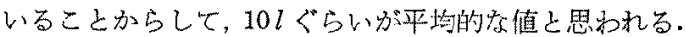

Table 3. Methane Fermentation of Poultry Wastes

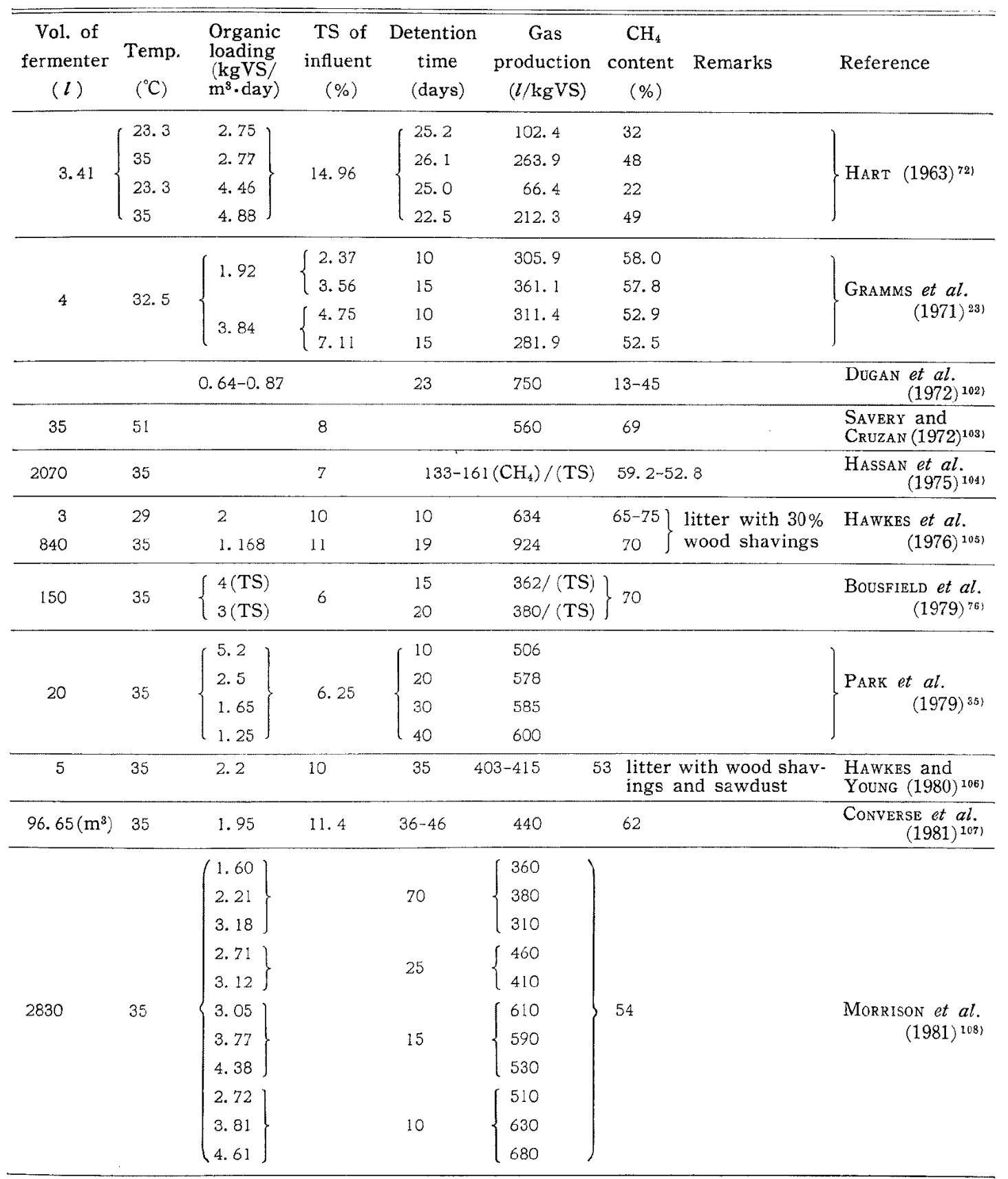


䍃の排泄物诖他の畜種に比べて周形物に近い形で排出 される.したがって，メタン醉酵に㻮しては水で稀貌し，

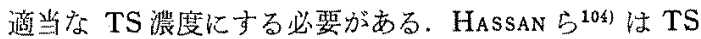

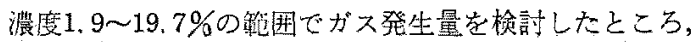

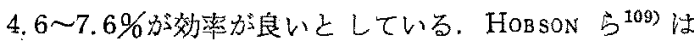
投入物の TS が 13\%にもなるとフンモニフ態窒素が $6,000 \mathrm{mg} / \mathrm{l}$, 揮発性脂肪酸吕 $18,000 \mathrm{mg} / \mathrm{l}$ になって醴醳

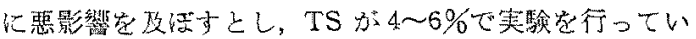
る.

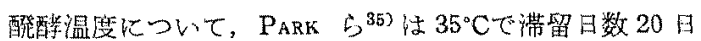
の場合醇醳槽当りの゙ガス発生量が $1.45 \mathrm{l} / \mathrm{l}$ ・日であっだ むの方, $30^{\circ} \mathrm{C} て ゙ 24$ 日の場合 $1.80 \mathrm{l} / \mathrm{l} \cdot$ 日, $25^{\circ} \mathrm{C}$ で 30 日の 場合 $1.38 \mathrm{l} / \mathrm{l}$ ・日, $20^{\circ} \mathrm{C}$ で 35 日の場含 $0.72 \mathrm{l} / \mathrm{l}$ ・日, $15^{\circ} \mathrm{C}$ で 50 日の埸合 $0.48 \mathrm{l} / \mathrm{l}$ 日上なり, $25^{\circ} \mathrm{C}$ 以下では急激 に娍少する結果在得ている. HASSANら ${ }^{101)}$ の研究では, $25^{\circ} \mathrm{C}$ 己 $50^{\circ} \mathrm{C}$ 亿お子るガス発生量は $35^{\circ} \mathrm{C}$ 約半分で斿。 た. ADDERLEY ら ${ }^{110)}$ 儿上れ海，酸生成期は TS 2.5\%で $25^{\circ} \mathrm{C}$ が適温だが，メタン生成期では TS $2.5 \%$ で $35^{\circ} \mathrm{C}$ が

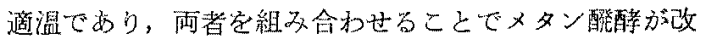
善されるとしている。

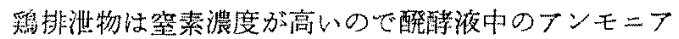
態窒素が問題となるが, CONVERSE $5^{107)}$ の研究では平均 $7,090 \mathrm{mg} / l$ でる順調なメタン醴醋が行われている．筆者 らの实験では $3,000 \mathrm{mg} / l$ 程度でも醗醉阻害が出ており， この点関しては, 前記の豚の項で論じた KROECKER ら ${ }^{55)}$ のような考方方導入し, さらに考察を加文る必要 があるう。

HILL と BARTH ${ }^{1111}$ は有機物負荷量を $0.4,0.8,1.6$, $3.2 \mathrm{~kg} / \mathrm{m}^{3} \cdot$ 日，滞留日数を $15 ， 30 ， 45$ 日とし，各々を

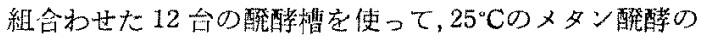
実験值とシミュレーションの結果を比較検討した。主な

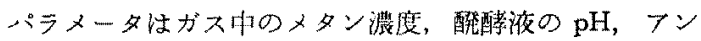
モニウムイオン濃度, VS 分解率、揮発性有蟣酸濃度, フ ルカリ度などであるが、突駼值とシミュレーションの結 果任良く一致し，醗醉が失敗するような条件設定をこの シミュレーションで予知できることが示唆された。

排㴹物を前処理し，生物分解性定高的た上でメ夕ン酕 醭に供しがス発生量を増加させようという試みるある。

Y ANG \& CHAN $^{1122}$ \& $\mathrm{pH} 1$ の硫酸加水分解処理をした鷄

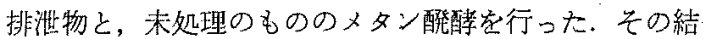
果, ガス発生量と分解性 COD との間にミカエリスーメ ソテン式が成立し，そのミカエリス定数は処理区の方が 小さいことから，処理区の分解性及びガス発生囟が高い 之述べている。

形の排社物の㘯命，前述のように固形状に近い形で排
出されるのが普通であり，現在の排泄物处理利用体系で 注，固形状の充宗乾燥なり堆肥化なりの方法をとること が望をしい，メタン醴醭に供する埸合には，排渵物に水 を加えなければならず，後の処理をかえって困奞にする ことがあるので注意要要する。

\section{3. エネルギー収支と経済性}

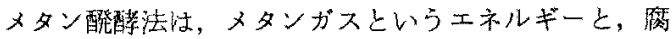
熟した液状き山う肥とのらたつの生産物学作り出す。乙 たがって，STAFFORD ら ${ }^{113)}$ が彼らの龧者の中で指摘して いるように，ふ如つの生産物のどちら主目的と考克る かでシステム全体肪变ってくる．即ち，エネルギ一生産

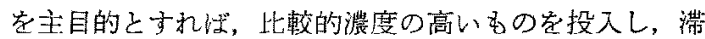

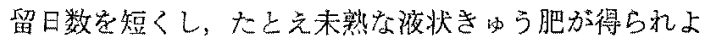
うとも，醴酻槽当りのガス発生量を最大にすべきで方る う。一方，噟熟した液状きゅう肥を卡目的とするならば，

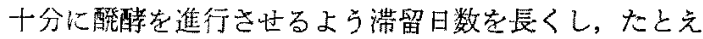

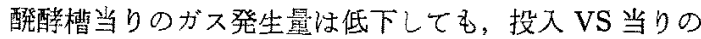
ガス発生量を最大にするようにすべきであるう。前まで の項では，主に後者の立場から論議を進めてきたが，本 项では前者の点を中心に述べてるない，

メタンガスを生産するためには，醴酥槽の保温などの エネルギーを外部から投入してやる必要がある。したが って，实際にメタン醴醉法察採用する場合，メタンガス 生産の net energy(ここでは，一般にガス発生総量から 保温などに要するガス量を差引いた余剩ガス量を言う) の正負が重要な問題となる。

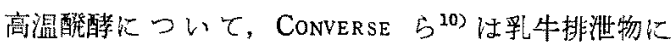
ついて net energy はマイナスになるとしているが,

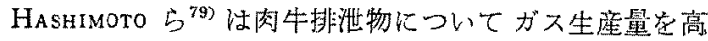
めることによって50\%の net energy 莐可能としている。 一方，中温酯醋ではほとえどの研究例がプラスである 述べている. MrLIs ${ }^{114)}$ は酸醳槽に $0.35 \mathrm{~kW} / \mathrm{m}^{3}$ の生産 性安認めており，PARK ら ${ }^{115)}$ は $137 \mathrm{~m}^{3}$ のメタン酸醉槽

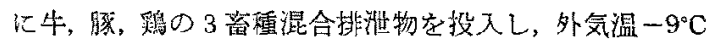
に下っだ冬期（1〜3月）でも net energy が 62\%あった としている. SUMmers と BouSFIELD ${ }^{116)}$ は豚排泄物メ夕 ン醴酵について, 発生がスの 40\%が槽の保温に必要であ り，残りのガス定電気比变換してポンブ動力に使用する としてす，その $25 \%$ \%゙余剩になると述べている. FISCHER

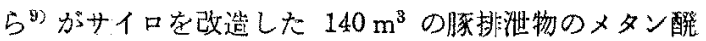
醳槽でも，発生がスの 53\% が net energy であった。

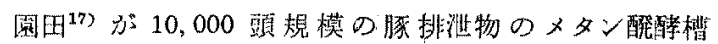
$\left(2,000 \mathrm{~m}^{3}\right)$ で武算したところで法, 冬 $\left(5^{\circ} \mathrm{C}\right)$ で $52.3 \%$, 夏 $\left(30^{\circ} \mathrm{C}\right.$ ) では $80.9 \%$ が余剩がス比なる。 


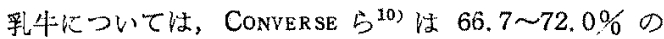
net energy 客得ている. Patelunas と $\operatorname{RegaN}^{75}$ は, 60 頭規模のメタン酸䤖槽では冬期 $\left(-18^{\circ} \mathrm{C}\right)$ でも，8.96 $\mathrm{kg} \mathrm{VS} / \mathrm{m}^{3}$ ・日の筫荷なら洁 $47.7 \%, 2.24 \mathrm{~kg} / \mathrm{m}^{3}$ ・日な

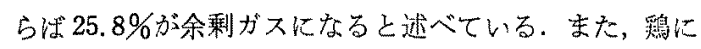
ついては, CONVERSE ら ${ }^{107)} の 76.65 \mathrm{~m}^{3}$ のメタン醗醳槽 で，発生がスを保温，攪㪵などのエネルギ一源使用し ても63\%が net energy として残るとしている.さらに WILLIAMS $5^{118,119)} 100$ 頭規模の酪農家, 1,000 頭規模 の肉牛フィードロットについて，エネルギー使用量を分 析し，艺の一部をメタンガスで賄えるという結諭它得て Wる.

このように, net energy ではプラスになるるのの，

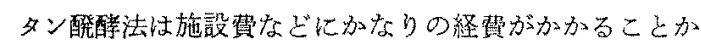
b，経齐性文考えると否定的結論が多い，まず，メタン

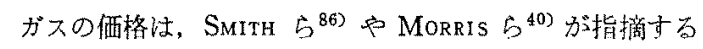
ように市販エネルギーの数倍の洒格になる。そして，

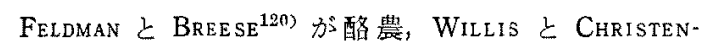

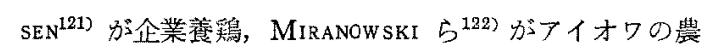

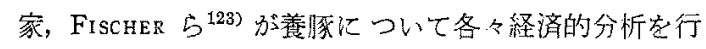

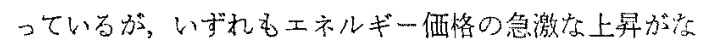
い限り，経済的には困難という給諭化達している。

したがって，経消的に成立させるためには，ガスの生 産量死飛躍的に上昇させるか，または施設費を大幅心安

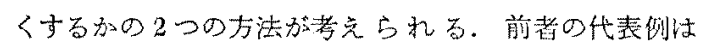
は HAsнmoto ら USDA のグループであらうし, 後者 は HAYES ら Cornell 大学のグループに代表されよう。

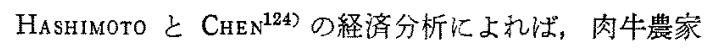
が自分で建設・運転するむのであれ恬 1,000〜2,000 頭

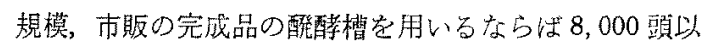
上の規模のフィードロットで経済的に成立つとしてい

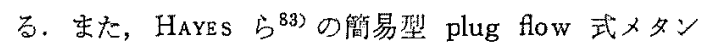
醴醏槽では 25 頭規模の酪農家でも経済的に戊り立つと している.

\section{おわりに}

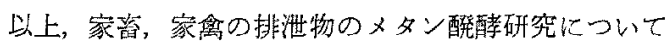
述べてきたもともとメタン醗酵柱自然界において沼気 や消化管内反応（特にルーメン反応）などの形で，人類 誔生以前加ら存在していたものであらう、そして，メタ ンガスを然料利用する技術にも古い歴史がある ${ }^{125)}$ わが 国の農家に打ける使用例や外国の例については簐者らが まとめた成珰126,127) 儿詳しい。 試験場老中心に実用化へ向けての活発な試験研究が行わ れて㧍り，確笑に成果を蕃積しつつるる。とれらの成果
については，紙面の都合で省略してしまったが，詳しく

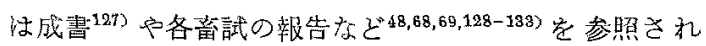
たい.

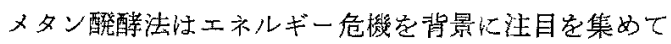

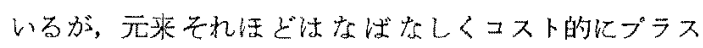
効果がある技術と梳文ないようである。しかし，園

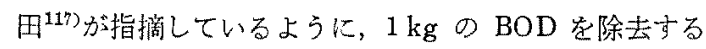
のに要する電気量は活性污泥法の約 $1 / 10$ ですみ，乙の

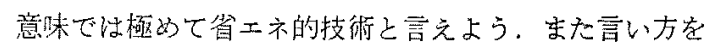
变えれげ，自然の掑理を巧双に利用している点で省工ネ 的とも言夫るう。乙して，罣来的には，工ネルギー生

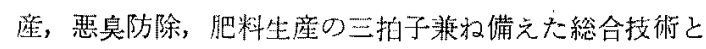
しての発展が期待される。

\section{文献}

1) 渡辺昭三（監修），蓄座公害刘策全望(昭利 56 年

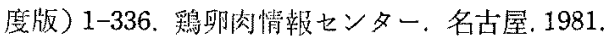

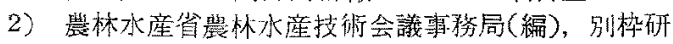

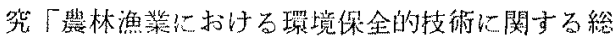

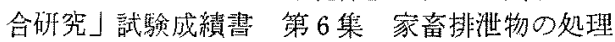
利用技䡓の開発。1-609. 東京. 1979 .

3) Livestock Waste: A Renewable Resource, Proceedings of the 4 th International Symposium on Livestock Wastes-1980. 1-430. ASAE. St. Joseph, MI. 1981.

4) Eckenfelder, W. W., Jr, Industrial Water Pollution Control, McGraw-Hill, U. S. A., 1966,

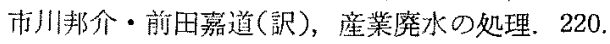
恒星社厚生閣, 束京. 1970 .

5) Zeikus, J.G., in Anaerobic Digestion (Stafrord, D. A., B. I. Wheatley and D. E. Hughes, eds.). 61-90. Applied Science. London. 1980.

6) Hobson, P. N. and B. G. Shaw, Water Res., 8: 507-516. 1974.

7) Iannotti, E. L., J.R. Fischer and D. M. Sievers, Appl. Environ. Microbiol., 36: 555-566, 1978.

8) Fischer, J.R., E. L. Iannotti, J.H. Porter and A. Garcia, Trans. ASAE, 22: 370-374. 1979.

9) Fischer, J. R., N. F. Meador, D. M. Sievers and C. D. Fulhage, Trans. ASAE, 22: 1129-1136. 1979.

10) Conyerse, J. C., R. E. Graves and G. W. Evans, Trans, ASAE, 20: 336-340, 1977.

11) Mackie, R. I. and M.P. Bryant, Appl. Environ. Microbiol, 41: 1363-1373. 1981.

12) Bryant, M. P., in Bergey's Manual of Determinative Bacteriology. 8 th ed. (Buchanan, R.E. and N.E. Girbons, eds.), 472-477. The Williams and Wilkins. Baltimore. 1974.

13) Balch, W. E., G. E. Fox, L. J. Magrum, C. R. Woese, and R.S. Wolfe, Microbiol. Rev., 43: 260-296. 1979. 
14) Hobson, P. N. and B. G. Shaw, Water, Res., 10: 849-852. 1976.

15) Wood, J. M., A. M. Allam, W. J. Brill and R. S. Wolfe, J. Biol. Chem, 240: 4564-4569. 1965.

16) Blaylock, B. A. and T.C. Stadtman, Arch. Biochem. Biophys., 116: 138-152. 1966.

17) Taylor, C. D., B. C. McBride, R. S. Wolfe and M. P. Bryant, J. Bacteriol, 120: 974-975. 1974.

18) TAyloR, C. D. and R. S. Wolfe, J. Biol. Chem., 249: 4879-4885. 1974.

19) Cheeseman, P., A. T. Wood and R. S. Wolfe, J. Bacteriol., 112: 527-531. 1972.

20) Mounfort, D. O. and R. A. Asuer, Appl. Environ. Microbiol, 35: 648-654. 1978.

21) McInerney, M.J., M. P. Bryant and D. A. StaFFORD, in Anaerobic Digestion (STAFFORD, D. A., B. I. Wheatley and D. E. Hughes, eds.) 91-98. Applied Science. London. 1980.

22) Taiganides, E. P., E. R. Baumann, H. P. Johnson and T. E. HAZEN, J. Agric. Eng. Res., 8: 327333. 1963.

23) Gramms, L. C., L. B. Polkowski and S. A. WITZEL, Trans. ASAE, 14:7-13. 1971.

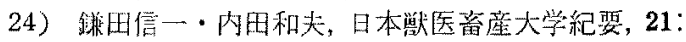
79-83. 1972.

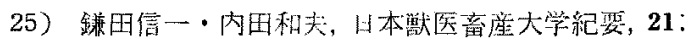
84-92, 1972.

26) Hobson, P. N. and B. G. Shaw, Water Res., 7: 437-449. 1973.

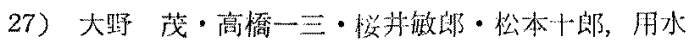
亡廃水, 16: 263-269. 1974.

28) Bousfield, S., P. N. Hobson and R. Summers, J. Appl. Bacteriol, 37: xi-xii. 1974.

29) Smith, R. E., M. J. Reed and J. T. Kiker, Trans. ASAE, 20: 1123-1128. 1977.

30) van Velsen, A. F. M., Neth. J. Agric. Sci., 25: 151-169. 1977.

31) Stevens, M.A, and D. D. Schulte, paper presented at the 1977 Annual Meeting of North Central Region of ASAE, paper No. NCR 77 1013, ASAE. St. Joseph. MI. 1977.

32) Huang, S. Y., K. T. Won, H. W. Wang and C. C. LiN, Proceedings of the National Science Council (Taiwan), 2：407-415. 1978.

33) Sievers, D. M. and D. E. Brune, Trans. ASAE, 21: $537-541,549,1978$.

34) Haga, K., H. Tanaka and S. Higaki, Agric. Wastes, 1: 45-55. 1979.

35) PARK, Y. D., N. J. PARK and J.H. Lim, Res. Rep. ORD(Korean), 21 (H. and Agric. Eng.): 53-60. 1979.

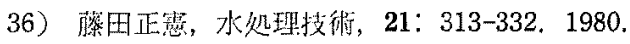

37) Summers, R. and S. Bousfield, Agric. Wastes, 2: $61-78.1980$.
38）黑田正和・油川情，下水道協会誌，17(196): 61-64. 1980.

39) IfEadi, C. N. and J. B. Brown, JR., in Energy, Agriculture and Waste Management (Jewell, W. J. ed.) 373-396. Ann Arbor Science. MI. 1975.

40) Morris, G. R., W. J. Jewell and G. L. Casler, in Energy, Agriculture and Waste Mangement (JeWell, W. J. ed.) 317-335. Ann Arbor Science. MI. 1975.

41）羽賀清典，畜産公害効策全畫（昭和 56 年度版）

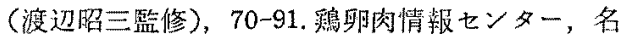
古屋. 1981.

42) Golueke, C. G., Biological Reclamation of Solid Wastes. 145-188. Rodale Press. Emmaus. PA. 1977.

43) Meynelt, P. J., Methane: Planning a Digester. 1-150. Shocken Books. New York. 1976.

44) Biomass Energy Institute, Biogas Production from Animal Manure, 1-20. Biomass Energy Institute. Winnipeg. Manitoba. 1978.

45) Jewel. , W. J. and R. C. Loenr, in Animal Wastes (Taiganides, E. P., ed.) 273-294. Applied Science. London. 1977.

46) van Velsen, A. F. M., H. R. Lettinga and D. den Ottelander, Neth, J, Agric. Sci., 27: 255-267. 1979.

47) Fellden, N. E. H., Agric. Wastes, 3: 75-79. 1981.

48）本多滕男，童産の研究，35：1027-1030. 1981.

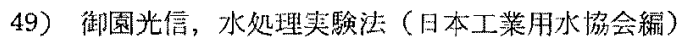
312-329. コロナ社. 東京. 1971.

50) Fujita, M., J. M. Scharer and M. Moo-Young, Agric. Wastes, 2: 177-184. 1980.

51) Fischer, J.R., E. L. Iannotti and D. M. Sievers, Agric. Wastes, 3: 201-214. 1981.

52) van Velsen, A. F. M., Water Res., 13: 995-999. 1979.

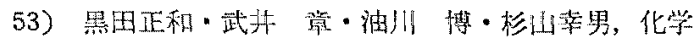
工学䛺文箱，6：609-613，1980.

54) Kugelman, I.J. and K. K. Chin, in Anaerobic Biological Treatment Process (Advances in Chemistry Series 105). 55-90. American Chemical Society. Washington, D. C. 1971.

55) Kroeker, E. J, D. D. Schulte, A. B. Sparling and H. M. LAPP, J. Water Pollut. Control Fed., 51: 718-727. 1979.

56) Hill, D. T. and R. A. Nordstedt, Agric. Wastes, 2: 135-156. 1980.

57) van Velsen, A. F. M., Neth. J. Agric. Sci., 27: 142-152. 1979.

58) Bryant, M. P., J. Anim. Sci, 48: 193-201. 1979.

59) Talganides, E. P., E. R. Baumann and T. E. HazEN, Compost Sci., 4 (2): 26-28. 1963. 
60) Hobson, P. N. and A. M. Robertson, Waste Treatment in Agriculture. 50. Applied Science. London. 1977.

61) Kamata, S., N. Kakitchi and K. Uchida, Bull. Npn. Vet. Zoothechnol. College, 28: 8-12. 1979.

62）田中正雄 - 園田頼和 - 清古義雄 - 平位正彦 - 小野 英男，発酵研報，21：169-180，1962。

63）羽賀清典・田中 博 -中鳰吉郎，日本畜産学会第 72 回大会讙演要旨. 64. 1981.

64）市川茂樹・金井昌邦，水処理技術，20：825-832. 1979 .

65）小野二良，メタンガス利用の理馀と鼠際、1-271. 文雅堂. 東京. 1963.

66) Welsh, F. W., D. D. Schulte, E. J. Kroeker and H. M. Lapp, Can. Agric. Eng. Res., 19: 122126. 1977.

67）田中 博 - 代永道裕 - 中䳡吉郎, 別杵研究「農林 漁業における環境保全的技術记関す万総合研究」 試験成績書 第 6 集 家音排泄物の処理利用技術 の開発 (農林水産省農林水産技術会議事務局編). 576-578. 1979.

68）平方明男 - 久保田建御 - 北原友栄 - 荻原正義 - 田 中章人・荻原宗弥・佐藤 満, 畜産技術, 316 : 1-8. 1981.

69）田盛詙昌，落豚の友，146：6-15，1981.

70）日中 博 - 代永道裕 - 中鳰吉郎, 別枠研究「農林 漁業における環境保全的技術に関卞る総合研究」 試験成績書 第 6 集 家畜排泄物の処理利用技䋍

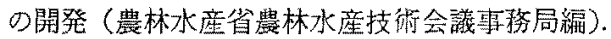
585-587. 1979.

71) Anglo, P. G., H. Tanaka and K. Haga, Philipp. J. Biol., 7: 247-258, 1978.

72) Hart, S. A., J. Water Pollut. Control Fed., 35: 748-757. 1963.

73) Dalrymple, W. and D. E. Proctor, Water Sewage Works, 114: 361-364. 1967.

74) VARel, V.H., H. R. IsaAC SON and M. P. Bryant, Appl. Environ. Microbiol., 33: 298-307. 1977.

75) Patelunas, G. M. and R. W. Regan, J. Environ. Eng. Div. ASCE, 103 (EE5): 851-861. 1977.

76) Bousfield, S., P. N. Hobson and R. Summers, Agric. Wastes, 1: 161-164. 1979.

77) Rajabapaiah, P., K. V. Ramanayya, S. R. Mohan and A. K. N. Reddy, Proc. Indian Acad. Sci, C2 (pt. 3): 357-363. 1979.

78) Hashimoto, A. G., R. L. Prior and Y.R. Chen, paper presented at the Great Plains Extension Seminar on Methane Production from Livestock Manure. 1-25. Liberal. KS. 1978.

79) Hashimoto, A. G., Y.R. Chen and R. L. Prior, J. Soil Water Conserv, 34: 16-19. 1979.

80) Hills, D. J., Trans, ASAE, 23: 122-126. 1980.

81) Hills, D. J. and J.R. Stephens, Agric. Wastes, 2: $103-118.1980$.
82) Rorick, M. B., S. L. Spahr and M.P. Bryant, J. Dairy Sci., 63: 1953-1956. 1980.

83) Hayes, T. D., W. J. Jeweli, S. Delz'Orto, K. J. Fanfoni, A. P. Leuschner and D. F. Sherman, in Anaerobic Digestion (Stafford, D. A., B. I. Wheatley and D. E. Hughes, eds.). 255-288. Applied Science. London. 1980.

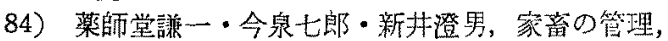
17: 31-32. 1981.

85) Jones, D. D., A. C. Dale, J. C. Nye and R. B. HARINGTON, Trans. ASAE, 24: 1282-1286, 1290, 1981.

86) Smith, R. J., M. E. Hein and T.H.Greiner, J. Anim. Sci., 48: 202-217. 1979.

87) Morris, G.R., W. J. Jewell and R. C. Loehr, in Food, Fertilizer and Agricultural Residue, (Loehr, R. C., ed.). 395-413. Ann Arbor Science, MI. 1977.

88) Wong-Chong, 'G. M., in Energy, Agriculture and Waste Management (Jewell, W. J., ed.). 361-372. Ann Arbor Science. MI. 1975.

89) Varel, V.H., A.G.Hashimoto and Y.R. Chen, Appl. Environ. Microbiol, 40: 217-222. 1980.

90) Hashimoto, A. G., V.H. Varel and Y. R. Chen, Agric. Wastes, 3: 241-256. 1981.

91) Hilis, D. J., Agric. Wastes, 1:267-278. 1979.

92) Hruls, D. J., Trans, ASAE, 23: 1500-1504. 1980.

93) Hills, D. J. and D. W. Rogerts, Agric. Wastes, 3: 179-189. 1981.

94) Robins, J.E., M. T. Arnold and S. L. Lacher, Appl. Environ. Microbiol, 38: 175-177. 1979.

95) Laura, R. D. and M. A. Idnan, J. Sci. Food Agric., 22: 164-167. 1971.

96) JaIn, M.K., R. Singh and P. Tauro, Agric. Wastes, 3: 65-73. 1981.

97) VARel, V.H. and A.G. НАshгмото, Appl. Environ Microbiol., 41: 29-34. 1981.

98) Hungate, R. E., D. W. Flecher and I. A. Dyer, J. Anim. Sci., 14: 997-1002. 1955.

99) Slytrr, L. L., Appl. Environ. Microbiol., 37: 283-288. 1979.

100) Chen, M. and M. J. Wolin, Appl. Environ. Microbiol, 38: 72-77. 1979.

101) Hill, D. T., D. T. Young and R. A. Nordstedt, Trans. ASAE, 24: 731-736. 1981.

102) Dugan, G. L., C. G. Golueke and W. J. Oswald, J. Water Pollut. Control Fed., 44: 432-440. 1972.

103) Savery, C. W. and D.C. Cruzan, J. Water Pollut. Control Fed, 44: 2349-2354. 1972.

104) Hassan, H. M., D. A. Belyea and A. E. Hassan, in Managing Livestock Wastes, Proc, the $3 \mathrm{rd}$ International Meeting. 244-247. ASAE. St. Joseph, MI. 1975. 
105) HaWkes, D., R. Horton and D.A. Stafford, Process Biochem., 11: 32-36. 1976.

106) Hawkes, F. R. and B. V. Young, Agric. Wastes, 2: 119-133. 1980.

107) Converse, J. C., G. W. Evans, K. L. Robinson, W. Gibbons and M. Gibbons, in Livestock

Waste: A Rewable Resource, Proc. the 4 th International Symposium on Livestock Wastes. 122-125. ASAE. St. Joseph, MI. 1981.

108) Morrison, S. R., P. Vohra, W. L. Shupe and D. J.Hills, in Livestock Waste: A Renewable Resource, Proc. the 4 th International Symposium on Livestock Wastes. 96-97, 100. ASAE. St. Joseph, MT. 1981.

109) Hobson, P. N., S. Bousfield, R. Summers and P. J. Mills, in Anaerobic Digestion (STAFFord, D. A., B. I. Wheatley and D. E. Hughes, eds.). 237-253. Applied Science. London. 1980.

110) Adderley, A. E., I. E. Smith and S. D. Probert, Appl. Energy, 2: 163-173. 1976.

111) Hill, D. T. and C. L. Barth, J. Water Pollut. Control Fed,, 49: 2129-2143. 1977.

112) Yang, P.Y. and K.K. Chan, in Food, Fertilzer and Agricultural Residues (LOsHR, R. C., ed.). 423-435. Ann Arbor Science. MI. 1977.

113) Stafford, D. A., D. L. Hawkes and R. Horton, Methane Production from Waste Organic Matter. 1-285. CRC Press. Boca Raton. FL. 1980.

114) Milis, P. J., Agric. Wastes, 1: 57-66. 1979.

115) PARK, Y. D., J. H. Lim and N. J. PARK, Res. Rep. ORD (Korean), 21 ( $H$. and Agric. Eng.): 61-68. 1979.

116) Summers, R. and S. Bousfield, Process Biochem., 11: 3-6. 1976.

117）園田頼和，廃水の生物処理 (高原義昌編)，167215. 地球社, 東京. 1980.

118) Williams, D. W., T. R. McCarty, W. W. Gunkel, D. R. Price and W. J. Jewell, in Energy, Agriculture and Waste Management (JEWELL, W.
J., ed.). 29-48. Ann Arbor Science. MI. 1975.

119) Williams, D. W., T.R. McCarty, G. R. Morris, W. W. Gunkel and D. R. Price, Trans. ASAE, 19: 1034-1044. 1976.

120) Feldman, S. L. and J. Breese, Resource Recov. Conserv., 3: 261-273. 1978.

121) Willis, C. E. and R. L. Christensen, in Agriculture and Energy (LOCKerEtz, W., ed.). 455468. Academic Press. New York. 1977.

122) Miranowski, J.A., E. R. Pidgeon and D. V. Peterson, in Agriculture and Energy (LockeRetz, W., ed.). 469-477. Academic Press. New York. 1977.

123) Fischer, J. R., D. D. Osburn, N. F. MEador and C. D. Fulhage, Trans. ASAE, 24: 1306-1310. 1981.

124) Hashimoto, A. G. and Y.R. Chen, in Livesock Waste: A Renewable Resource, Proc. the $4 \mathrm{th}$ International Symposium on Livestock Wastes. 129-132. ASAE. St. Joseph. MT. 1981.

125) Tietjen, C., in Energy, Agriculture and Waste Management (JEWELL, W. J. ed.). 247-259. Ann Arbor Science. MI. 1975.

126）㹃村生活総合研究センター(編)，〈らしとメタン カ゚ス，1-126. 農村生活総合研究センタ一。東京. 1981.

127）䪪林水産技衔情報協会(編)，メタンガス利用の新 技街，1-127. 嶄林水産技術情報協会，東京. 1980 。

128）大野木利成，昭和 50 年度山形具立畜産試験場試験 研究報告, 19：87-97. 1976.

129）築城文明 - 中林大治郎 - 姖野愿士，昭和 51 年度大 分県震業技術センター蓄産部試験研究成績望, 18: 57-65. 1976.

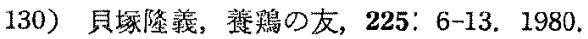

131）郡山秀文・阿野俊男, 香川目坠座試験場研究報告, 18: $35-44.1980$.

132）北村元茂・川井顕正・下西 和，高知県畜産試験 場研究報告，11：62-68. 1980 .

133）林希史雄・兵頭只義・石本的一，愛媛県畜産試験 場研究報告, 4：2-27, 1980. 